\title{
A Study on the Effectiveness of Inventory in Working Capital Management of Select Cement Companies in Meghalaya.
}

\author{
*Yoowanka Lyngdoh, Dr.K.C.Biswal \\ Research Scholar, Department of Management, NEHU, Tura Campus \\ Associate Professor, Department of Management, NEHU, Tura Campus \\ Corresponding Author: Yoowanka Lyngdoh
}

\begin{abstract}
Inventory management which is an integral part of the working capital management is viewed as a fundamental catalyst of ensuring corporate profitability. It occupies the most strategic position in the structure of working capital of most business enterprises. It constitutes the largest component of current asset in most business enterprises. In the sphere of working capital, the efficient control of inventory has passed the most serious problem to the cement mills because about two-third of the current assets of mills are blocked in inventories. The turnover of working capital is largely governed by the turnover of inventory. The study intends to explore conceptually the inventory management options in ensuring corporate profitability.
\end{abstract}

Keywords: Inventory, working capital, Inventory Turnover,

\section{Introduction}

Working capital is regarded as the difference between the current assets and the current liabilities or in other words as net assets. Padachi (2006) opined that management of working capital is important in ensuring the financial health of all businesses. This could be viewed in the fact that most often the amount invested in the fact that most often the amount invested in working capital are high in proportion to total assets employee this and therefore justifies why it should be utilized efficiently. Equally the manner in which working capital is managed directly affects the liquidity and profitability of the corporate firm and consequently its net worth. (Smith 1980)

Efficient working capital management therefore, tries to maintain a balance liquidity and profitability within the realm of business operations. The impact of efficiency of working capital management corporate profitability have been a central focus of most empirical research for quite number of years. (Shin \& Soenan, 1998; Deloof 2003; Lazandis \& tryfonidis, 2006: filbeck \& Krueger, 2005).

\section{Literature Review}

Various previous researches discussed extensively on the relationship between working capital management and profitability of firm related to different environments. Shin and Soeren (1998) used a sample of 58,985 firm`s years covering the period 1975-1994 in order to investigate the relationship between the nettrade cycle that was used to measure efficiency of working capital management and corporate profitability. The study found a strong negative relationship between the length of firm`s net-trade cycle and its profitability.

Deloof (2003) used a sample of 1,009 large Belgian non-financial firms for the 1992-1996 periods to investigate the relationship between working capital management and corporate profitability. The result indicated a negative relationships between profitability that was measured by Gross Operating Income and the cash conversion cycle, number of days accounts receivable, inventories. According to his suggestion, manager may tend to increase profitability by reducing the number of days account receivable and inventories, according to his analogy, less profitable firms wait longer to pay theirs.

Lazaridis and Tryfomidis (2006) used a sample of 131 listed companies in the Alliens stock exchange for the period 2001-2004 to investigate the relationship between working capital management working capital management and corporate profitability. The results revealed that there was a statistical significance between profitability which was measured through gross operating profit and cash conversion cycle. In their final submission, they maintain that the managers could create value for shareholders by handling correctly the cash conversion cycle and keeping each different component to an optimum level.

Raheman and Nasr (2007) studied the effects of various components working capital management on net operating profitability. They selected a sample of 94 Pakistani firms listed on Karachi stock exchange for a period of six years from 1999-2004. A negative relationship was established, between the components of working capital management as average collection period, inventory turn-over in days, cash conversion cycle 
and the profitability. Equally among their findings was establishing a positive relation ship between the firm`s size measured by natural algorithm of sales and profitability.

Singh and Pandy (2008) studied the relationship between working capital management's components on profitability of Hindalco Industries Limited for period covering 1990 to 2007. The findings of the study indicated that, there was a statistical significance between the current ratio, liquidity ratio, receivable turnover ratio, and total assets ratio to profitability. Conclusively, Afza and Nasir (2009) used a sample of 204 nonfinancial firms listed on Karachi Stock Exchange (KSE) for the period 1998-2005 to investigate the relationship between working capital management policies and firm`s profitability. The results of findings signified a negative relationship between the profitability of firms and the degree of aggressiveness of working capital investment and financing policies.

\section{Inventory management}

Mostly in manufacturing companies, inventory usually include supplies, raw materials, work-inprocess and finished goods. All these forms of inventory needs to be financed and their efficient management can increase firm`s profitability (Stanley and Geoffrey, 1997). An optimum inventory level depends on sales, so sales must be forecasted before target inventories can be established. Moreover, because errors in setting inventory levels lead to loss of sales or excessive carrying costs, inventory management is quite important. Therefore, firms use sophisticated computer systems to monitor their inventory holdings (Brigham and Houston, 2007). Although inventory management may be considered as outside the main stream of finance, it is however, necessary to emphasize it's important and potential effects to corporate profitability of manufacturing companies. Inventories are lists of stock-raw materials, work-in-progress or finished goods waiting to be consumed in either production or to be sold. Inventory is a very important variable because it reflects the average number of days of stock held by the firm. Longer storage times represent a greater investment in inventory for a particular level of operations (Olufemi \& Olubanjo, 2009). Inventories represent the second largest asset category for manufacturing companies, next only to plant and equipment 15 to 30 percent. Given substantial investment to inventories, the importance of inventing management cannot be over-emphasized (Prasana,2000). Two major intrigues arise whenever, we tend to discuss or inventing management, they are, what should be the size of the order? And what level should the order is placed? Those two questions are best answered through the Economic Ordering Quantity model (EOQ) (Prasana 2000). Singh, (2000) found that, the size of inventory directly affects working capital and its management. He suggested that inventory was major component of working capital, and needed to be carefully controlled

\section{Measure of Effectiveness of Inventory Management}

1. Size of Inventory = Total inventory/Total Current assets

2. Size of Raw material Inventory = Raw material inventory/Total inventory

3. Size of Work in Process Inventory = Work in process Inventory/Total Inventory

4. Size of Stores and Spares parts Inventory = Stores and Spares parts inventory/Total Inventory

5. Size of Finished Goods Inventory = Finished goods inventory/Total inventory

6 . Inventory holding period $=365 /$ Inventory turnover ratio

\section{Control and Review}

The efficiency of inventory control affects the flexibility of the firm. There are several tools of inventory control. Some of these are:

(1) The economic order quantity which enables determination of optimal size of order to place on the basis of demand or usage of the inventory.

(2) The technique of safety stocks to overcome problems of uncertainty.

(3) The order point formula, which tells us, the optimal point at which to reorder a particular item of inventory. Together, these tools provide the means for determining an optimal average level of inventory for the firm. Ratio analysis has a wider application as a measure of inventory control among most manufacturing firms. Some of the important ratios are explained below:

(1) Inventory to Sales (Total Inventory/Sales for the Period).The ratio explains variations in the level of investment. An increase in inventory levels, substantially beyond that which might be expected from an increase in sales, may reflect such phenomena as the result of a conscious policy shift to higher stock levels, of unintended accumulation of unsold stocks, and of inventory speculation, or simply stocking in anticipation of an almost certain surge of orders.

(2) Inventory Turnover (Cost of Goods Sold/Average Inventory). The ratio tells us the rapidity with which the inventory is turned over into receivables through sales. Generally, the higher the inventory turnover, the more efficient the management of a firm is. However, a relatively high inventory turnover ratio may be the result of 
too low a level of inventory and frequent stock outs. Therefore, the ratio must be judged in relation to the past and expected future ratios of the firm and in relations of similar firms or the industry average or both.

(3) Sales to Inventory (Annual Net Sales/Inventory at the End of Fiscal Period) The ratio indicates the volume of sales in relation to the amount of capital invested in inventories. When inventory for a firm is larger in relation to sales (the condition which causes it to have a lower net sales to inventory ratio than other firms) the firm's rate of return is less since it has more working capital tied up in inventories than has the firm with a higher ratio.

(7) Inventory to Net Working Capital (Inventory/Net Working Capital).The ratio explains the amount of inventory per rupee of equity/long-term financed portion of current assets. A higher ratio may mean greater amount of net working capital investment in inventory. In order to control each category of inventory, the following ratios can be calculated.

\section{Methodology}

The secondary data used in the study were collected for a period from 2005-2006 to 2014-15 from the database maintained and made available by several organizations viz, cement manufacturers association, Information has been sourced from Books, Newspapers, and Websites. The following five cement companies are taken for the study and they are Mawmluh Cherra Cement Ltd, Jaintia Cement Ltd, Virgo Cement Ltd,Meghalaya Cement Ltd and Cement Manufacturing CompanyLtd.

\section{Limitations of the Study}

The study is limited to five cement companies only. The time and cost involved in the collection of data is a major constraint. The results of the study may not be generalized for all the cement industries in India. The source of data is secondary in nature.

\section{Objectives}

1.To measure the effectiveness of Inventory in working capital management of select cement companies in Meghalaya.

2.To study the efficiency of inventory control affects the flexibility of the cement companies.

Data Analysis and Interpretations

The size of inventory of selected cement companies has been presented in table 1

Table.1. Size of Inventory of Selected Cement Companies for the years from 2005-06 to 20014-15

\begin{tabular}{|l|l|l|l|l|l|}
\hline Year & $\begin{array}{l}\text { Mawmluh Cherra } \\
\text { Cement Limited }\end{array}$ & $\begin{array}{l}\text { Jaintia Cement } \\
\text { Limited }\end{array}$ & $\begin{array}{l}\text { Virgo Cement } \\
\text { Limited }\end{array}$ & $\begin{array}{l}\text { Meghalaya } \\
\text { Limited }\end{array}$ & $\begin{array}{l}\text { Cement } \\
\text { Manufacturing } \\
\text { Company Limited }\end{array}$ \\
\hline $2005-06$ & 0.58 & 0.81 & 0.15 & 0.30 & 0.55 \\
\hline $2006-07$ & 0.54 & 2.92 & 0.71 & 0.02 & 0.69 \\
\hline $2007-08$ & 0.70 & 3.24 & 0.48 & 0.64 & 0.44 \\
\hline $2008-09$ & 0.67 & 0.46 & 0.07 & 0.15 & 0.12 \\
\hline $2009-10$ & 0.70 & 0.63 & 0.89 & 0.20 & 0.14 \\
\hline $2010-11$ & 0.75 & 0.52 & 0.08 & 0.26 & 0.54 \\
\hline $2011-12$ & 0.34 & 0.23 & 0.07 & 0.02 & 0.38 \\
\hline $2012-13$ & 0.24 & 0.34 & 0.06 & 0.03 & 0.34 \\
\hline $2013-14$ & 0.56 & 0.22 & 0.09 & 0.63 & \\
\hline $2014-15$ & 0.29 & 0.19 & & & 0.27 \\
\hline
\end{tabular}

\section{Sources:annual report}

Five cement companies under study have kept at different levels of inventory during the study period from 2005-06 to 20014-15. Table 6.1 gives a clear picture of inventory kept by the five companies. The size of inventory of all the cement companies' shows fluctuating trend throughout the study period except Cement Manufacturing Company that shows decreasing trend. The minimum size of inventory in Mawmluh Cherra Cement Company is 0.24 (2012-13). Jaintia Cement Company is 0.19 (2014-15), Virgo Cement is 0.06 (201213), 221Meghalaya Cement is 0.02 (2011-12) and in Cement Manufacturing is 0.12 (2008-09). The maximum size of inventory in Mawmluh Cherra Cement Company is 0.75 (2010-11), Jaintia Cement is 3.24 (2007-08), Virgo Cement is 0.89 (2009-10), and Meghalaya Cement is 0.64 (2007-08) and in Cement Manufacturing Company is 0.69 (2006-07). The size of Raw Material Inventory of selected companies has been given in table 2 . 
Table .2. Size of Raw Material Inventory of Selected Cement Companies for the years from 2005-06 to 20014-15

\begin{tabular}{|l|l|l|l|l|l|}
\hline Year & $\begin{array}{l}\text { Mawmluh Cherra } \\
\text { Cement Limited }\end{array}$ & $\begin{array}{l}\text { Jaintia Cement } \\
\text { Limited }\end{array}$ & $\begin{array}{l}\text { Virgo Cement } \\
\text { Limited }\end{array}$ & $\begin{array}{l}\text { Meghalaya Cement } \\
\text { Limited }\end{array}$ & $\begin{array}{l}\text { Cement } \\
\text { Manufacturing } \\
\text { Company Limited }\end{array}$ \\
\hline $2005-06$ & 5.21 & 7.18 & 3.47 & 1.60 & 0.17 \\
\hline $2006-07$ & 5.75 & 5.14 & 9.01 & 2.55 & 0.08 \\
\hline $2007-08$ & 1.09 & 5.03 & 9.27 & 1.25 & 0.20 \\
\hline $2008-09$ & 1.23 & 0.01 & 1.84 & 6.59 & 0.15 \\
\hline $2009-10$ & 9.79 & 0.22 & 1.19 & 4.92 & 0.08 \\
\hline $2010-11$ & 2.87 & 8.27 & 4.47 & 0.07 & 0.71 \\
\hline $2011-12$ & 1.69 & 1.95 & 3.41 & 0.44 & 0.22 \\
\hline $2012-13$ & 1.59 & 1.53 & 1.32 & 3.47 & 0.37 \\
\hline $2013-14$ & 2.63 & 2.54 & 7.09 & 2.06 & \\
\hline $2014-15$ & 2.79 & 2.85 & 7.03 & & \\
\hline
\end{tabular}

Sources: Annual report

Five cement companies under study have kept at different levels of raw material inventory during the study period from 2005-06 to 2014-15. Table 6.2 gives a clear picture of raw material inventory kept by the five companies. The size of raw material inventory of all the cement companies shows fluctuating trend throughout the study period except Mawmluh Cherra Cement and Virgo Cement which shows decreasing trend. The minimum size of raw material inventory in Mawmluh Cherra Cement is 1.09 ((2007-08), Jaintia Cement is 0.01 (2008-09), Virgo Cement is 1.19 (2009-10), Meghalaya Cement is 0.07 (2011-12) and in Cement Manufactuirng Company is 0.08 (2006-07). The maximum size of raw material inventory in Mawmluh Cherra Cement is 9.71 (2009-10) . Jaintia Cement is 8.27 (2010-11), Virgo Cement is 9.27 (2007-08), and Meghalaya Cement is 6.59 (2008-09) and in Cement Manufacturing Company is 0.71 (2010-11). The size of Stores and Spares Inventory of selected companies have been presented in Table .3 .

Table.3. Size of Stores and Spares Inventory of Selected Cement Companies for the years from 2005-06 to 2014-15

\begin{tabular}{|l|l|l|l|l|l|}
\hline Year & $\begin{array}{l}\text { Mawmluh Cherra } \\
\text { Cement Limited } \\
\text { Limited Cement }\end{array}$ & $\begin{array}{l}\text { Virgo Cement } \\
\text { Limited }\end{array}$ & $\begin{array}{l}\text { Meghalaya } \\
\text { Limited }\end{array}$ & $\begin{array}{l}\text { Cement } \\
\text { Manufacturing } \\
\text { Company Limited }\end{array}$ \\
\hline $2005-06$ & 9.88 & 1.64 & 5.88 & 4.96 & 7.59 \\
\hline $2006-07$ & 2.06 & 1.94 & 2.89 & 9.99 & 0.57 \\
\hline $2007-08$ & 2.89 & 2.55 & 6.42 & 3.45 & 0.20 \\
\hline $2008-09$ & 1.55 & 2.98 & 1.21 & 7.07 & 1.55 \\
\hline $2009-10$ & 2.12 & 9.52 & 3.04 & 6.36 & 0.18 \\
\hline $2010-11$ & 2.62 & 3.55 & 4.84 & 1.44 & 0.52 \\
\hline $2011-12$ & 1.61 & 6.30 & 5.51 & 0.15 & 5.96 \\
\hline $2012-13$ & 1.06 & 5.77 & 3.77 & 0.33 & 5.47 \\
\hline $2013-14$ & 5.88 & 4.32 & 2.74 & 1.38 & 9.66 \\
\hline $2014-15$ & 1.28 & 2.79 & 4.67 & \\
\hline
\end{tabular}

Souces: annual report

Five cement companies under study have kept at different levels of stores and spare parts inventory during the study period from 2005-06 to 2014-15. Table 6.3 gives a clear picture of stores and spare parts inventory kept by the five companies. The size of stores and spare parts inventory of all the cement companies shows fluctuating trend throughout the study period except Mawmluh Cherra Cement which shows decreasing trend. The minimum size of stores and spare parts inventory in Mawmluh Cherra Cement is 1.06 (2012-13), Jaintia Cement is 1.64 (2005-06), Virgo Cement is 1.21 (2008-09), Meghalaya Cement is 0.15 (2012-13) and in Cement Manufacturing Company is 0.18 (2009-10). The maximum size of stores and spare parts inventory in Mawmluh Cherra Cement is 9.88 (2005-06) , Jaintia Cement is 9.52 (2009-10), Virgo Cement is 6.42 (2007-08) and Meghalaya Cement is 9.99 (2006-07) and in Cement Manufacturing Company is 9.66 (2013-14).

The Size of Works of Process Inventory of Selected Companies has been given in Table .4.

Table .4. Size of Work of Progress Inventory of Selected Cement Companies for the years from 2005-06 to 2014-15

\begin{tabular}{|l|l|l|l|l|l|}
\hline Year & $\begin{array}{l}\text { Mawmluh Cherra } \\
\text { Cement Limited } \\
\text { Limited }\end{array}$ & $\begin{array}{l}\text { Jaintia Cement } \\
\text { Limited }\end{array}$ & $\begin{array}{l}\text { Meghalaya Cement } \\
\text { Limited } \\
\text { Manufacturing } \\
\text { Company Limited }\end{array}$ \\
\hline $2005-06$ & 4.63 & 0.13 & 3.21 & 4.66 & 0.02 \\
\hline $2006-07$ & 1.89 & 0.04 & 0.25 & 2.50 & 0.06 \\
\hline $2007-08$ & 5.58 & 0.03 & 5.45 & 5.67 & 0.73 \\
\hline $2008-09$ & 2.62 & 0.24 & 2.23 & 6.69 & 0.27 \\
\hline $2009-10$ & 0.25 & 0.19 & 9.34 & 3.60 & 0.15 \\
\hline $2010-11$ & 1.71 & 0.26 & 6.78 & 9.19 & 0.14 \\
\hline $2011-12$ & 2.12 & 0.82 & 3.17 & 0.16 & 0.72 \\
\hline $2012-13$ & 1.89 & 0.47 & 3.40 & 0.42 & 0.53 \\
\hline $2013-14$ & 0.26 & 0.87 & 8.25 & 2.31 & 0.12 \\
\hline $2014-15$ & 1.62 & 0.11 & 0.71 & 1.16 & 0.21 \\
\hline
\end{tabular}

Sources: Annual Report 
Five cement companies under study have kept at different levels of Work-in-Process inventory during the study period from 2005-06 to 2014-15. Table 6.4 gives a clear picture of Work in Process inventory kept by the five companies. The Work in Process inventory of all the cement companies shows fluctuating trend throughout the study period. The minimum Work-in-Process inventory in Mawmluh Cherra Cement is 0.25 (2009-10). Jaintia Cement is 0.03 (2007-08), Virgo Cement is 0.25 (2006-07), Meghalaya Cement is 0.16 (2011-12) and in Cement Manufacturing Company is 0.02 (2005-06). The maximum Work-in-Process inventory in Mawmluh Cherra Cement is 5.58 (2007-08), Jaintia Cement is 0.82 (2011-12), Virgo Cement is 9.34 (200910), Meghalaya Cement is 9.19 (2010-11) and in Cement Manufacturing Company is 0.73 (2007-08). Five cement companies under study have kept at different levels of finished goods inventory during the study period from 2005-06 to 2014-15 has been presented in Table .5.

Table 5. Size of Finished Goods Inventory of Selected Cement Companies for the years from 2005-06 to 20014-15

\begin{tabular}{|l|l|l|l|l|l|}
\hline Year & $\begin{array}{l}\text { Mawmluh Cherra } \\
\text { Cement Limited }\end{array}$ & $\begin{array}{l}\text { Jaintia Cement } \\
\text { Limited }\end{array}$ & $\begin{array}{l}\text { Virgo Cement } \\
\text { Limited }\end{array}$ & $\begin{array}{l}\text { Meghalaya } \\
\text { Company Limited }\end{array}$ & $\begin{array}{l}\text { Cement } \\
\text { Manufacturing } \\
\text { Company Limited }\end{array}$ \\
\hline $2005-06$ & 8.93 & 0.17 & 1.83 & 6.02 & 0.05 \\
\hline $2006-07$ & 1.88 & 0.05 & 1.57 & 3.33 & 0.26 \\
\hline $2007-08$ & 5.56 & 0.04 & 1.33 & 0.33 & 0.33 \\
\hline $2008-09$ & 7.34 & 0.32 & 3.34 & 2.66 & 0.17 \\
\hline $2009-10$ & 0.03 & 0.26 & 0.33 & 3.53 & 0.20 \\
\hline $2010-11$ & 1.89 & 0.35 & 4.32 & 4.69 & 0.38 \\
\hline $2011-12$ & 3.86 & 1.09 & 2.02 & 0.83 & 0.79 \\
\hline $2012-13$ & 1.03 & 0.62 & 1.09 & 0.38 & 0.66 \\
\hline $2013-14$ & 0.39 & 1.16 & 3.85 & 4.35 & 0.95 \\
\hline $2014-15$ & 1.62 & 0.01 & 0.21 & 0.90 \\
\hline
\end{tabular}

\section{Souces: annual report}

Table 6.5 gives a clear picture of finished goods inventory kept by the five companies. The size of finished goods inventory of all the cement companies shows fluctuating trend throughout the study period. The minimum size of finished goods inventory in Mawmluh Cherra Cement is 0.03 (2009-10), Jaintia Cement is 0.01 (2014-15), Virgo Cement is 0.21(2014-15), Meghalaya Cement is 0.33 (2007-08) and in Cement Manufacturing Company is 0.05 (2005-06). The maximum size of finished goods inventory in Mawmluh Cherra Cement is 8.93 (2005-06), Jaintia Cement is 1.16 (2013-14), Virgo Cement is 4.32(2010-11), Meghalaya Cement is 8.17(2009-10) and Cement Manufacturing Company is 0.95(2013-14) Five cement companies under study have kept at different levels of inventory holding period during the study period from 2005-06 to 2014-15 has been given in Table .6.

Table .6. Inventory holding period of Selected Cement Companies for the years from 2005-06 to 2014-15

\begin{tabular}{|l|l|l|l|l|l|}
\hline Year & $\begin{array}{l}\text { Mawmluh Cherra } \\
\text { Cement Limited } \\
\text { Limited }\end{array}$ & $\begin{array}{l}\text { Jaintia Cement } \\
\text { Limited }\end{array}$ & $\begin{array}{l}\text { Virgo Cement } \\
\text { Limited }\end{array}$ & $\begin{array}{l}\text { Ceghalaya } \\
\text { Manufacturing } \\
\text { Company Limited }\end{array}$ \\
\hline $2005-06$ & 27 & 119 & 172 & 193 & 23 \\
\hline $2006-07$ & 31 & 25 & 31 & 80 & 25 \\
\hline $2007-08$ & 45 & 26 & 22 & 115 & 24 \\
\hline $2008-09$ & 44 & 142 & 59 & 31 & 64 \\
\hline $2009-10$ & 41 & 115 & 142 & 28 & 21 \\
\hline $2010-11$ & 21 & 159 & 151 & 90 & 59 \\
\hline $2011-12$ & 33 & 33 & 96 & 60 & 105 \\
\hline $2012-13$ & 32 & 21 & 34 & 24 & 120 \\
\hline $2013-14$ & 170 & 23 & 38 & 44 & 97 \\
\hline $2014-15$ & 29 & 34 & 27 & 87 \\
\hline
\end{tabular}

\section{Sources: annual report}

Table 6.6 gives a clear picture of inventory holding period kept by the five companies. The inventoryholding period of all the cement companies shows fluctuating trend throughout the study period expect Meghalaya Cement that shows decreasing trend. The minimum inventory holding period in Mawmluh Cherra Cement is 21 (2010-11), Jaintia Cement is 21 (2012-13), Virgo Cement is 22 (2007-08), Meghalaya Cement is 28 (2009-10) and in Cement Manufacturing Company is 21 (2009-10). The maximum inventory-holding period in Mawmluh Cherra Cement is 170 (2013-14), Jaintia Cement is 119 (2005-06), Virgo Cement is 172 (200506), and Meghalaya Cement is 193 (2005-06) and in Cement Manufacturing Company is 105 (2011-12). 


\section{Inventory Turnover (Cost of Goods Sold/Average Inventory)}

The ratio tells us the rapidity with which the inventory is turned over into receivables through sales. Generally, the higher the inventory turnover, the more efficient the management of a firm is. However, a relatively high inventory turnover ratio may be the result of too low a level of inventory and frequent stock outs. Therefore, the ratio must be judged in relation to the past and expected future ratios of the firm and in relations of similar firms or the industry average or both. Five cement companies under study have kept at different levels of inventory turnover during the study period from 2005-06 to 2014-15 has been given in Table .7.

Table .7. Inventory Turnover of Selected Cement Companies for the years from 2005-06 to 2014-15

\begin{tabular}{|l|l|l|l|l|l|}
\hline Year & $\begin{array}{l}\text { Mawmluh Cherra } \\
\text { Cement Limited }\end{array}$ & $\begin{array}{l}\text { Jaintia Cement } \\
\text { Limited }\end{array}$ & $\begin{array}{l}\text { Virgo Cement } \\
\text { Limited }\end{array}$ & $\begin{array}{l}\text { Meghalaya Cement } \\
\text { Limited }\end{array}$ & $\begin{array}{l}\text { Cement } \\
\text { Manufacturing } \\
\text { Company Limited }\end{array}$ \\
\hline $2005-06$ & 0.35 & 4.12 & 4.85 & 0.35 & 0.24 \\
\hline $2006-07$ & 0.36 & 0.16 & 1.53 & 6.75 & 0.18 \\
\hline $2007-08$ & 0.52 & 0.58 & 3.82 & 0.30 & 8.47 \\
\hline $2008-09$ & 0.53 & 3.93 & 2.83 & 0.28 & 0.55 \\
\hline $2009-10$ & 0.07 & 2.55 & 1.34 & 0.05 & 0.76 \\
\hline $2010-11$ & 0.08 & 4.56 & 3.80 & 3.60 & 0.36 \\
\hline $2011-12$ & 1.55 & 5.69 & 2.88 & 3.32 & 0.20 \\
\hline $2012-13$ & 0.16 & 3.43 & 1.51 & 0.20 & 0.17 \\
\hline $2013-14$ & 0.30 & 4.25 & 9.49 & 0.26 & 0.26 \\
\hline $2014-15$ & 2.31 & 0.86 & 1.07 & 0.16 \\
\hline
\end{tabular}

Sources: Annual report

Table 6.7 gives a clear picture of inventory kept by the five companies. The inventory turnover of all the cement companies shows fluctuating trend throughout the study period except Mawmluh Cherra Cement that shows increasing trend. The minimum inventory turnover in Mawmluh Cherra Cement is 0.07 (2009-10), Jaintia Cement is 0.16 (2006-07), Virgo Cement is 1.07 (2014-15), Meghalaya Cement is 0.05 (2009-10) and in Cement Manufacturing Company is 0.16 (2014-15). The maximum inventory turnover in Mawmluh Cherra Cement is 2.31(2014-15), Jaintia Cement is 5.69 (2011-12), Virgo Cement is 9.49 (2013-14), and Meghalaya Cement is 6.75 (2006-07) and in Cement Manufacturing Company is 8.47 (2007-08).

\section{Sales to Inventory (Annual Net Sales/Inventory at the End of Fiscal Period)}

The ratio indicates the volume of sales in relation to the amount of capital invested in inventories. When inventory for a firm is larger in relation to sales (the condition which causes it to have a lower net sales to inventory ratio than other firms) the firm's rate of return is less since it has more working capital tied up in inventories than has the firm with a higher ratio. Five cement companies under study have kept at different levels of Sales to total inventory during the study period from 2005-06 to 2014-15 has been shown in Table .8.

Table .8. Sales to Total Inventory of Selected Cement Companies for the years from 2005-06 to 2014-15

\begin{tabular}{|l|l|l|l|l|l|}
\hline Year & $\begin{array}{l}\text { Mawmluh Cherra } \\
\text { Cement Limited }\end{array}$ & $\begin{array}{l}\text { Jaintia Cement } \\
\text { Limited }\end{array}$ & $\begin{array}{l}\text { Virgo Cement } \\
\text { Limited }\end{array}$ & $\begin{array}{l}\text { Meghalaya Cement } \\
\text { Limited }\end{array}$ & $\begin{array}{l}\text { Virgo } \\
\text { Manufacturing } \\
\text { Company Limited }\end{array}$ \\
\hline $2005-06$ & 0.93 & 5.67 & 7.32 & 4.51 & 4.31 \\
\hline $2006-07$ & 1.06 & 0.90 & 1.55 & 6.23 & 5.31 \\
\hline $2007-08$ & 1.41 & 1.07 & 3.77 & 8.97 & 3.48 \\
\hline $2008-09$ & 1.32 & 7.05 & 0.03 & 1.09 & 2.01 \\
\hline $2009-10$ & 1.03 & 5.13 & 1.35 & 9.31 & 7.19 \\
\hline $2010-11$ & 1.35 & 0.08 & 4.12 & 5.47 & 6.34 \\
\hline $2011-12$ & 0.24 & 9.82 & 2.94 & 5.02 & 5.77 \\
\hline $2012-13$ & 2.59 & 6.89 & 1.54 & 5.49 & 2.23 \\
\hline $2013-14$ & 2.23 & 0.61 & 9.38 & 5.32 & \\
\hline $2014-15$ & 1.57 & 1.02 & 5.19 & & 1.98 \\
\hline
\end{tabular}

\section{Souces: Annual report}

Table 6.8 gives a clear picture of Sales to Total inventory kept by the five companies. The Sales to Total inventory of all the cement companies shows fluctuating trend throughout the study period. The minimum Sales to Total Inventory in Mawmluh Cherra Cement is 0.24 (2011-12). Jaintia Cement is 0.08 (2010-11), Virgo Cement is 0.03 (2008-09), Meghalaya Cement is 0.38 (2014-15) and in Cement Manufacturing Company is 1.98 (2014-15). The maximum Sales to Total Inventory in Mawmluh Cherra Cement is 2.59 (2012-13), Jaintia Cement is 9.82 (2011-12), Virgo Cement is 9.38 (2013-14), and Meghalaya Cement is 9.31 (2009-10) and in Cement Manufacturing Company is 7.13 (2009-10). 


\section{Inventory to Net Working Capital (Inventory/Net Working Capital)}

The ratio explains the amount of inventory per rupee of equity/long-term financed portion of current assets. A higher ratio may mean greater amount of net working capital investment in inventory. The Inventory of net Working Capital of selected cement companies has been given in table .9.

Table .9. Inventory to net Working Capital of Selected Cement Companies for the years from 2005-06 to 201415

\begin{tabular}{|l|l|l|l|l|l|}
\hline Year & $\begin{array}{l}\text { Mawmluh Cherra } \\
\text { Cement Limited } \\
\text { Limited Cement }\end{array}$ & $\begin{array}{l}\text { Virgo Cement } \\
\text { Limited }\end{array}$ & $\begin{array}{l}\text { Meghalaya } \\
\text { Limited }\end{array}$ & $\begin{array}{l}\text { Cement } \\
\text { Manufacturing } \\
\text { Company Limited }\end{array}$ \\
\hline $2005-06$ & 1.34 & 3.05 & 2.14 & 1.97 & 1.56 \\
\hline $2006-07$ & 1.16 & 1.46 & 1.19 & 4.55 & 1.44 \\
\hline $2007-08$ & 8.07 & 1.40 & 1.70 & 3.31 & 1.50 \\
\hline $2008-09$ & 8.41 & 2.56 & 6.19 & 1.18 & 5.62 \\
\hline $2009-10$ & 8.87 & 3.16 & 2.62 & 1.31 & 1.71 \\
\hline $2010-11$ & 1.68 & 2.29 & 3.21 & 4.03 & 6.12 \\
\hline $2011-12$ & 1.10 & 1.10 & 2.54 & 6.01 & 3.48 \\
\hline $2012-13$ & 1.13 & 1.73 & 3.83 & 1.47 & 3.75 \\
\hline $2013-14$ & 2.12 & 1.59 & 1.06 & 3.19 & 4.19 \\
\hline $2014-15$ & 1.37 & 1.07 & 9.40 & 8.24 & 4.05 \\
\hline
\end{tabular}

\section{Sources: Annual report}

The inventory of net working capital of all the cement companies' shows fluctuating trend throughout the study period except Mawmluh Cherra Cement, which shows decreasing trend. The minimum value of inventory in net working capital in Mawmluh Cherra Cement is 1.10(2011-12), Jaintia Cement is 1.07 (201415), Virgo Cement is 1.06 (2013-14), Meghalaya Cement is 1.18 (2008-09) and in Cement Manufacturing Company is 1.71 (2009-10). The maximum value of inventory to net working capital in Mawmluh Cherra Cement is 8.87 (2009-10), Jaintia Cement is 3.16 (2009-10), Virgo Cement is 9.40 (2014-15), Meghalaya Cement is 8.24 (2014-15) and in Cement Manufacturing Company is 6.12

(2010-11)

\section{Conclusions}

The foregoing study in the chapters leads to many conclusions about the Inventory management in five cement companies of Meghalaya.It could be deduced from the discussion so far that importance of inventory management, which is a component of working capital management cannot be overemphasized. Efficient and effective management of inventories ensures business survival and maximization of profit which is the cardinal aim of every firm. More so an efficient management of working capital through proper and timely inventory management ensures a balance between profitability and liquidity trade-offs. As already pointed out in earlier the biggest limitation of the study had been that a large number of companies had to be left out because cement is not their main business though they are big producers of cement. Further, beyond data published in annual accounts no further data were made available by any company. Therefore, detailed probe could not be made on many aspects which have been pointed out at relevant places. Subject to these limitations following conclusions can be drawn from the study. The basic objective of working capital management is to minimise cost to the firm whether managing cash, receivables (Sunday debtors) or inventory or miscellaneous current assets, minimize risk to the company on receivables, ensure just level of inventory to operate full level of capacity with minimum inventory. It also implies that as far as possible miscellaneous current assets should be utilised for company's operations. In other words the working capital management should aim to optimise production and sales with minimum risk and cost.

It seems from the analysis of data of selected sample companies that in cement industry by and large there is no proper working capital management. Every decision has been left out to market forces without working out cost benefit analysis or applying various formulas suggested by experts. This is very much evident from wide variations in various ratios from company to company and in different years for the same company. The cash management is very faulty as a result of which cash ratio to total current assets and to sales are very high for the cement industry. With the above general observations one can draw number of conclusion about the economic health of the industry and various aspects of working capital. This state of cement industry is expected to continue in near future too because new capacity is being created faster than growth in demand. This has increased competition and working capital management has become more difficult. On the one side customers have to be accommodated to compete in the market but at the same time all possible economies must be achieved in management of cash, receivables and inventory to maintain and improve profitability. 


\section{Reference}

[1] Afza, T. and Nazir, M. (2009). Impact of aggressive working capital management policy on firm`s profitability. The IUP Journal of Applied Finance, 15(8) 20-30.

[2] Brigham, E.C and Houston, M. (2007). Foundations of Financial Management. Dryden press publishers.

[3] Deloof, M. (2003). Does working capital management affect profitability of Belgian firms?. Journal of Business Finance and Accounting, 30 (3-4).

[4] Eljelly, A.M. (2004). Liquidity-Profitability Trade-offs: An empirical investigation in an emerging market. International Journal of commerce and management. 14(2), 48-61.

[5] Filbeck, G, and Krueger, T. (2005). Industry related differences in working capital management . Journal of Business, 20 (2), 11-18. Journal of financial management and analysis, 19(1), 26-35.

[6] Lamberson, M. (1995). Changes in working capital of small firms in relation to changes in economic activity. Journal of Business, $10(2), 45-50$.

[7] Lazaridis, I. and Tryfonidis, D. (2006). Relationship between working capital management and profitability of listed companies in Athens stock exchange.

[8] Olufemi, I.F and Olubanjo, T.A. (2009). Working capital management and corporate profitability: Evidence from panel data analysis of selected quoted companies in Nigeria. Research Journal of Business Management, 3 (3), 73 - 84.

[9] Padachi, K. (2006): Trends in working capital management and its impact on firm`s performance: An analysis of mountain small manufacturing firms. International Review of Business Research Papers (2), 45-56.

[10] Prasana C., (2000). Financial Management, Mc Graw Hill Publish Publishing Company.

[11] Raheman, A. \& Nasr, M. (2007).Working capital management and profitability, case of Pakistan firms. International Review of Business Research Papers, 3(1), 279-300.

[12] Shin, H.H. and Soenen, L. (1998). Efficiency of working capital management and corporate profitability.Financial Practice and Education, 8(2), 37-45.

[13] Singh, J.P. and Pandy, S. (2008). Impact of working capital management in the profitability of Hindalco Industries Limited. Kfai University, Journal of Financial Economics, 6 (4), 62-72.

[14] Smith. (1980). Profitability versus liquidity trade-offs in working capital management. In readings on the management of working capital. New York, Paul: West

IOSR Journal of Business and Management (IOSR-JBM) is UGC approved Journal with Sl. No. 4481, Journal no. 46879. Yoowanka Lyngdoh. "A Study on the Effectiveness of Inventory in Working Capital Management of Select Cement Companies in Meghalaya." IOSR Journal of Business and Management (IOSR-JBM) 19.7 (2017): 41-48. 